\title{
SCIDiC
}

International Journal of Forensic Science \& Pathology (IJFP)

ISSN: 2332-287X

\section{Insect Activitiy and Its Relationship to decay Rates of Rat cadaver in Solapur District}

Research Article

Tejashri Lokhande ${ }^{1 *}$, Vikram Hankare ${ }^{2}$

${ }^{1}$ UG Student, Department of Forensic Science, Yashwantrao Chavan Institute of Science (Autonomous), Satara, Maharashtra, India.

${ }^{2}$ Assistant Professor, Department Of Forensic Science, Yashwantrao Chavan Institute Of Science (Autonomous), Satara Maharashtra, India.

\section{Abstract}

The purpose of this study to collect the data on the specific insects. which insects found on decay cadaver. This cadaver were placed, at various times of the day, in open wooded area. This all Data were collected on the basis of daily activities and entire decay cycle of Insects population. Which insects arrived at frequented cadaver. This analysis of the data show that there is a direct correlation between the rate of decay and the activity of carrion insect families which found on decay cadaver.

Introduction: The main purpose of this research was to provide a more reliable method for determining the time interval since death of decayed on the basis of entomological and climatic factor. Decay rate of cadaver have a direct relationship to the activity and seasonality pattern of carrion frequenting insects.

Aim: Insect Activitiy and Its Relationship to decay Rates of Rat cadaver in Solapur District.

Objective To find out time interval since death. To collect data on the specific insects which are found in association with decay cadaver.

Methodology: Took the Rat cadaver and placed cage ,this cage placed in open wooded area for decomposition. Then recorded daily activity of insects like growth, changes of cadaver, counted insect populations and types of insects.

Conclusion: This experiment performed in summer season. In this season was found very rapidly growth of insects and decomposition of cadaver. In this experiment observed the different type of insects growth and it's populations. The house flies mostly observed in all decomposition stages. The other type of insects arrived on cadaver for specific period or specific stages.

Keywords: Criminal Investigation; Time Interval Since Death; Carrion Insect Activity; Rat Cadaver.

\section{Introduction}

In this topic I was studied about insect activity and relationship to decay rates of Rat cadaver. The Rat cadaver were placed in open wooded area. And also studied about in which stage which kind of insects attracted on rat cadaver. How amount of insects present on cadaver and it's populations, this all details are mentioned in this paper. Then also studied about adult larvae cycle. And find " time interval since death "of Rat cadaver. During the interval of March 9,2021 through March 14,2021 observation of the rat cadavers yeilded significant information concerning the relationship of insect activity to rat decay rates.

\section{Insect activity after death:}

The insects used in this method are those that arrive first on the corpse, that is, the Calliphoridae or blowflies. These flies are at- tracted to a corpse very soon after death. They lay their eggs on the corpse, usually in a wound, if present, or if not, then in any of the natural orifices. Following types of insects species found in during the decompositional stages.

\section{Types of insects:}
1) Blow fly (Calliphoridae)
2) Flesh fly (Sarcophagidae)
3) House fly (Muscidae)
4) Unknown fly
5) Rove beetle (Staphylinidae)
6) Shining mold beetle

\section{Method and Material}

\section{Materials}

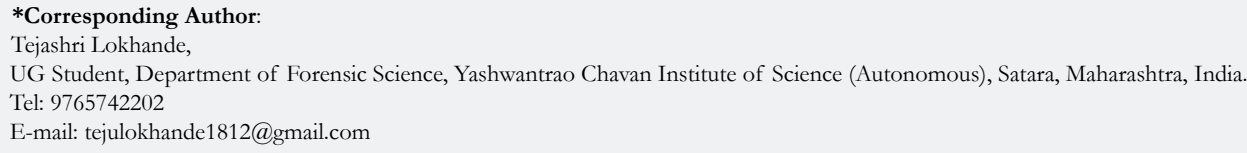

Citation: Tejashri Lokhande, Vikram Hankare. Insect Activitiy and Its Relationship to Decay Rates of Rat Cadaver in Solapur District. Int J Forensic Sci Pathol. 2021 ;8(4):464-467. doi: http://dx.doi.org/10.19070/2332-287X-2100097

Copyright: Tejashri Lokhande ${ }^{\circ} 2021$. This is an open-access article distributed under the terms of the Creative Commons Attribution License, which permits unrestricted use, distribution and reproduction in any medium, provided the original author and source are credited. 
Figure 1. Unknown fly similar as chess skipper.

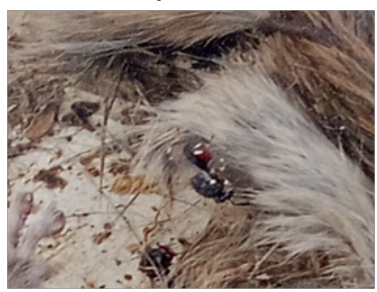

Figure 3. Cage.

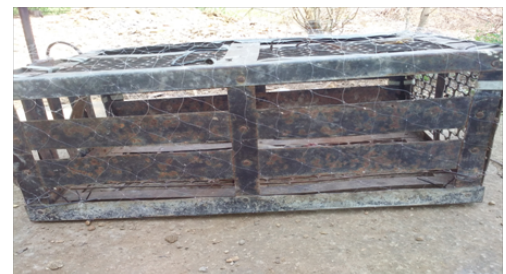

Figure 5. House fly recovered.

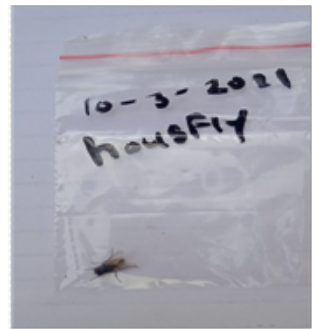

Figure 2. House flies on Rat cadaver.

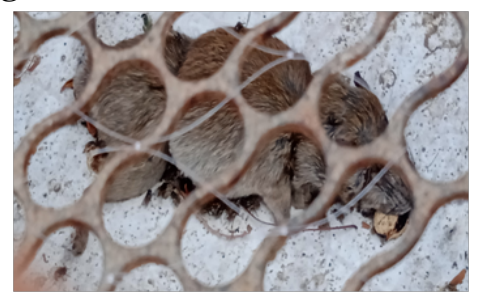

Figure 4. Larvae packaged in bag from nearest cadaver.

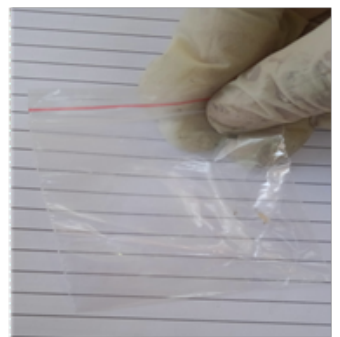

Figure 6. Shining mold beetle zip lock recovered on rat cadaver.

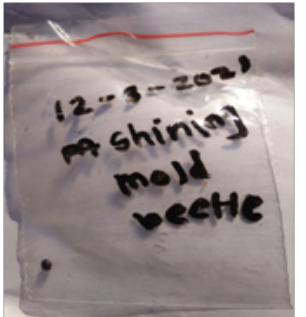

1) Rat cadaver

2) Concrete floor

3) Mesh hardware cloth

4) Cage

5) Pen

6) pencil

7) Scale

8) Notebook

\section{Methodology}

After death of rat placed in the decay facility within their death. Experimental studies were conducted in solapur. Firstly located in open place area of Chandapuri, Solapur. Then took a cage. Then placed the rat cadaver in this cage. This cage placed on above the concrete floor (in $36{ }^{\circ} \mathrm{C}$ temprature). And covering the cage by mesh hardware cloth. Mesh hardware cloth used because this provide easy access to the cadaver for insects, but prevent the destruction and loss of skeletal material by rodents. It is allow for better observations and photography. Recorded the daily the data concering climatic conditions, body decomposition and insect activitiy. Each daily observational period start at noon and last from one and three depending on the degree of insect activity. Then took photograph in various angle. Then carefully performed steps insect collection and identification.

\section{Insect collection and identification}

Insect data consisted of daily observational records of insects activity, types , feeding abundance, colour of insects and reproductive activity. Photograph of different types of insects and their activity were also taken. Some insects present in nearby soil and nearest area of cadaver. Adult Diptera (flies)form collected by us- ing aerial insect net (And also weard the handgloves). Then larvae coleoptera were collected by using dissecting forceps. Then packaged the ziplock bags and also mentioned date, Name of insects on this bags.

\section{Observed stages of decomposition}

During the interval of March 9,2021 through March 14,2021 observation of the rat cadavers yeilded significant information concerning the relationship of insect activity to rat decay rates. The cadaver observed undergoing successional stages of decomposition. The first stage observed was the "fresh stage". In this stages ants present on his mouth and whole body of rat cadaver. This stage began upon the death of the individual and continued until the early stages of bloating. During warm weather bloating was observed to begin within a one days.

The second stage of decomposition observed was the "bloated stage. "This stage began with the onset of bloating and ended with cessation of bloating. Duration of this stage continued for approximately two to three days during warm weather. Abdomen is distended.

Third stage observed was the "decay stage". Commencement of this stage began when bloating ceased and when most of the cadaver remnants were relatively dry. Duration of the decay stage was approximately three to four days during warm weather. During this "decay stage" the skin cracked in several areas, allowing the entrance of air, which facilitated the process of aerobic protein decomposition.

\section{Post decay stage/Dry stage}

The fourth stage of decomposition observed was the "post de- 
a) Figure. Fresh stage.

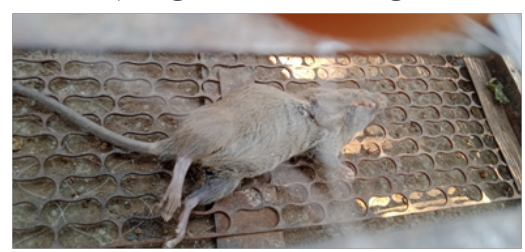

c) Decay Stage(House flies present on abdomen).

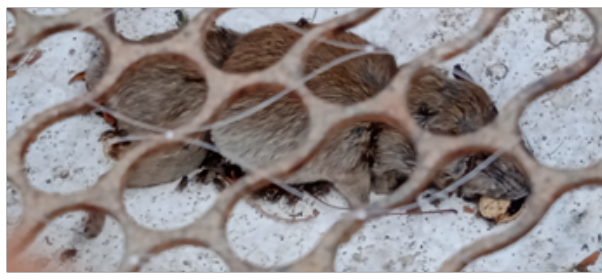

e) Post decay stage.

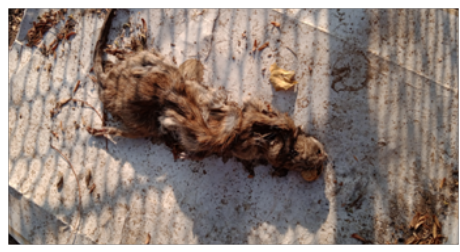

cay". In this stages only skin, cartillage, and bones left on the carcasses. It is stage dominated by beetles. Duration of the post decay stage was approximately four to five days.

The fifth stage of decomposition observed was the "Dry stage". Only hair and bones left few bettles remain mites present. The final stage of decomposition observed was the" dry stage ".in this stage adult larvae present in it.

\section{Carrion insect populations observed}

Different types of insect families and species were observed throughout the decompositional cycle of the cadavers. The majority of these insects can be basically classified as carrion insects. Carrion insects are those insects which feed on decomposing flesh. After death of animal, that is exposed to the environment, the process of decomposition begins. As decomposition take place, Then enzymatic and bacterial breakdown the body tissue $\mathrm{s}$ occur. The breakdown tissue in turn releases various odors. This odors is main reason of various types of insects attracted on cadaver. In this experiment includes order Diptera and order Coleoptera likes, housefly, blowfly, fleshfly, shining mold beetle, rove beetle, unknown flies similar as chess skipper fly etc.

\section{Order Diptera}

Order Diptera means which is insects (Flies) present during the fresh and bloated stages of the Rat cadaver. The major Diptera family observed were the Calliphoridae (Blow flies), Muscidae (HousFlies), Sarcophagidae (Flesh flies).

\section{Calliphoridae (Blow flies)}

It is present in bloated and decay stage

Colour- metallic blue or green to copper

Size - 5-13mm

10 March 2021- 2 to 3 species b) Bloated stagestage.

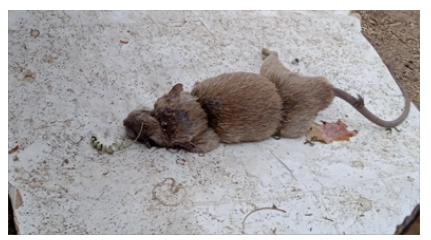

d) Decay stage few maggots present on cadaver.

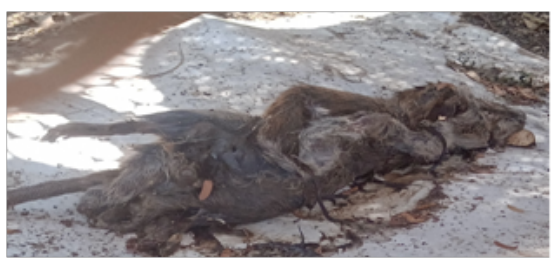

f) Dry stage.

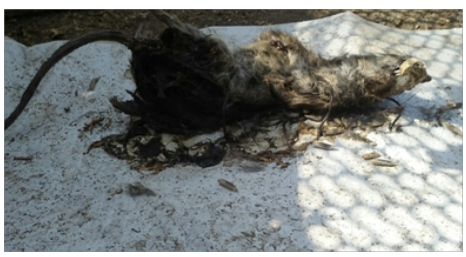

11 March 2021- 5to 6 species

\section{Family muscidae (House flies)}

It is present in all season but mostly observed bloated ,decay and post decay stages

Colour -lack black coloring and usually dull colored grey.

Size- $5-9 \mathrm{~mm}$

10 March 2021- 5 to 6 species

11 March 2021- 30 to 50 species

12 March 2021- 5 to 6 species

\section{Family sarcophagidae( flesh fly):}

It is present in bloated, decay and post decay stages.

Colour- similar look like muscidae fly

Size $-7-15 \mathrm{~mm}$

10 March $2021-2$ to 3 species

11 March 2021-5 to 6 species

12 March 2021- small amount

\section{Order coleoptera}

Order Diptera means which is insects (Flies) present during the decay and dry stages of the Rat cadaver.

\section{Family Staphylinidae (Rove beetle):}

It is present in post decay stage.

Colour -black or brown

Size -3- $5 \mathrm{~mm}$

12 March 2021- 6 to 10 species

Family Staphylinidae(Shining mold beetle):

It is present in post decay stage.

Colour - Shiny Black 
Table 1. Insect Populations.

\begin{tabular}{|c|c|c|c|c|c|c|c|c|c|}
\hline & Ants & $\begin{array}{c}\text { House- } \\
\text { flies }\end{array}$ & $\begin{array}{c}\text { Blow } \\
\text { files }\end{array}$ & $\begin{array}{c}\text { Flesh } \\
\text { flies }\end{array}$ & $\begin{array}{c}\text { Un- } \\
\text { known } \\
\text { flies }\end{array}$ & $\begin{array}{c}\text { Shining } \\
\text { mold } \\
\text { beetles }\end{array}$ & $\begin{array}{c}\text { Rove } \\
\text { beetles }\end{array}$ & $\begin{array}{c}\text { Pupae/larvae } \\
\text { Length }\end{array}$ & Day's \\
\hline Fresh & $20-30$ & & & & & & & & 1 day \\
\hline Bloated & & $5-6$ & $2-3$ & $2-3$ & & & & & 2 to 3 \\
\hline Decay & & $30-50$ & $5-6$ & $5-6$ & & & & & 3 to 4 \\
\hline Post decay & & $5-6$ & & Present & $3-8$ & $5-9$ & $6-10$ & $3 \mathrm{~mm}$-8mm & 4 to 5 \\
\hline Dry & & Present & & & & & & $\begin{array}{c}50-80 \mathrm{more} \\
14 \mathrm{~mm}-15 \mathrm{~mm}\end{array}$ & 5 to 6 \\
\hline
\end{tabular}

Size $-2-3 \mathrm{~mm}$

12 March 2021- 5 to 9 species

\section{Unknown flies}

It is present in post decay stages. And present on hair of Rat cadaver. It is similar to chess skipper fly.

Colour -black or white point on feather, red legs and abdomen Size - 3-5mm.

12 March 2021- 3-8 species

\section{Result and Discussion}

The decomposition of cadavers was found to occur most rapidly during the summer season. These Carrion insect populations found on the cadavers were at their is a greatest during these seasons. This correlation between the rate of decay and number of carrion insects, which is indicates that insects are major factor responsible for decomposition. These stages are the fresh, bloated, decay, postdecay, and dry stages. The growth and development of particular fly species which fed on the cadavers were also observed to occur at rates previously established by entomologist.

The decompositional rate of cadaver observed, On the basis of five stages fresh stage, bloated stage, decay stage, advanced decay stage and dry stages. And various types of insects and larvae are observed in specific stage and specific time duration.

And also studied the growth of adult larvae. In this stages ob- served the following types of insects like, housefly, blowfly, fleshfly, shining mold beetle, rove beetle, unknown flies similar as chess skipper fly etc.

\section{Conclusion}

In this experiment includes the insects like ants, Houseflies, blow flies, flesh flies, shining mold beetles, Rove beetles, unknown flies (this fly similar as chess Skipper) etc. In this experiment observed the different types of insects growth and it's populations. The house flies mostly observed in all decomposition stages. The other type of insects arrived on cadaver for specific period or specific stages. This experiment performed in summer season. In this season very rapidly growth of insects and decomposition of Rat cadaver was found.

\section{References}

[1]. Rodriguez, William C III. Insect Activity and Its Relationship to Decay Rates of Human Cadavers in East Tennessee. Master's Thesis, University Of Tennessee. 1982.

[2]. Payne JA. A summer carrion study of the baby pig Sus scrofa Linnaeus. Ecology. 1965 Sep;46(5):592-602.

[3]. Payne JA, King EW, Beinhart G. Arthropod succession and decomposition of buried pigs. Nature. 1968 Sep 14;219(5159):1180-1. Pubmed PMID: 5675643.

[4]. Curran CH. The families and genera of North American Diptera. The Families and Genera of North American Diptera.. 1934.

[5]. Reed Jr HB. A study of dog carcass communities in Tennessee, with special reference to the insects. American midland naturalist. 1958 Jan 1:213-45.

[6]. Daily R. C Time of Death. Abstract; program American Academy of Forensic Science, 34th Annual Meeting, Orlando, Florida, 1982. 